\title{
The ambient environment of the Gangetic sediments of chalcolithic period
}

\author{
D P AGRAWAL, M N DESHPANDE,* S N RAJAGURU ${ }^{\dagger}$ and \\ BHASKAR ROY \\ Physical Research Laboratory, Ahmedabad 380009 \\ -Archaeological Survey of India, New Delhi \\ †Deccan College, Poona \\ MS received 31 December 1977
}

\begin{abstract}
There is considerable controversy regarding the mode of deposition of the OCP culture-associated sediments in the Gangetic valley and their ecological implications. SEM and sedimentologic studies show a fluvial mode of deposition of sediments originally derived from a glacial cnvironment.
\end{abstract}

Keywords. SEM; OCP cultures; Gangetic sediments; environment.

\section{Introduction}

The sediments associated with the Ochre Coloured Pottery (OCP), which is datable to c. 1800 B.C., (Huxtable et al 1972) in the Gangetic valley look very different from the regular habitational deposit and are bereft of all human artifacts except for a few occasional OCP sherds. Since the OCP culture is the oldest Chalcolithic culture of Uttar Pradesh with reported contacts with the Indus Civilization (c. 24001700 B.C.) and association with the Copper Hoards (a culture marked by distinctive copper tools found in caches), the depositional environment of the associated sediments assumes importance.

It is significant to find an explanation for such a large scale distribution of a detritallooking sediment and a near total absence of regular habitational deposits. Was it due to an intense aeolian activity indicating severe arid conditions, amounting to desertic conditions, in an area where today there is $100-200 \mathrm{~cm}$ annual rain fall? Or was there a great deluge? Was there a vast lake caused by tectonic uplift of the Gangetic alluvium? Answers to these questions are crucial to an understanding of the environmental conditions in which the OCP man was living, but unfortunately there is still considerable controversy about the origin of these sediments (Agrawal 1971, Lal 1968, 1971-72, Sharma 1977).

We, therefore, took up the problem afresh. Samples were collected from the two typical sites of District Saharanpur, U. P., viz. Nasirpur and Ambakheri. Both the sites are known for their OCP associations. The sediment samples were subjected to sedimentologic, mineralogic and scanning electronic microscopic (SEM) analyses to reconstruct their depositional environment. Our results are briefly reported below. 


\section{Sedimentologic analyses}

The OCP associated sediments are of a uniform texture and their thickness varies from 1 to $2 \mathrm{~m}$. The top shows a humic horizon and the bottom layer is full of kankar nodules. Table 1 gives the sedimentological and mineralogical characteristics of the sediments obtained from Nasirpur 1 and 2 and Ambakheri in western U. P. The samples are silty sand to sandy silt in nature but poorly sorted (table 1). The poor sorting is mainly because of the bimodal nature of deposition indicated by the presence of coarse sand as well as silt. Coarse sand ranges from $15.9 \%$ to $41.9 \%$ whereas clay varies from $9 \cdot 1 \%$ to $21.6 \%$ (table 1 ). These sediments, therefore, seem to have been transported during floods under intermittent suspension (indicated by the presence of coarse and fine sand) and also under continuous suspension (indicated by the presence of silt and clay fraction) (Blatt et al 1972). The samples analysed by Lal (1971-72) have been assigned by him to an aeolian activity. But the presence of a significant percentage of coarse sand clearly indicates a bimodal deposition.

Mineralogic analyses show (table 1) a major presence of micaceous minerals (muscovite, biotite and chlorite) in the coarser fraction. Any long range wind transport should have abraded the fragile mica component into clay sized fractions (Glennie 1970). The presence of coarse mica goes against an aeolian mode of transport.

Thus both the bi-modal nature of its deposition and its mineralogic composition indicate that the deposit is fluvial and not aeolian.

Table 1. Sedimentologic and mineralogic analyses of OCP sediments. A bimodal deposition showing both coarse sand and silt as also the presence of coarse mica rules out acolian deposition.

(Munsell Colour No. 7.5 YR 5/4)

\begin{tabular}{|c|c|c|c|c|c|c|c|c|}
\hline $\begin{array}{l}\text { Sample } \\
\text { No. }\end{array}$ & Site & $\begin{array}{l}\text { Texture } \\
\text { classifi- } \\
\text { cation }\end{array}$ & $\begin{array}{l}\text { Mid } \\
\text { value } \\
(\mathrm{mm})\end{array}$ & $\begin{array}{l}\text { Trask } \\
\text { sorting } \\
\text { coeff. }\end{array}$ & $\begin{array}{l}\text { Coarse } \\
\text { sand \% } \\
(2-0 \cdot 2 \\
\mathrm{mm})\end{array}$ & $\begin{array}{l}\text { Silt and } \\
\text { fine sand } \\
\% \\
(0 \cdot 2-0 \cdot 002 \\
\text { mm })\end{array}$ & $\begin{array}{l}\text { Clay } \\
(<0.002 \\
\mathrm{mm})\end{array}$ & Minerals \\
\hline SEM-12 & $\begin{array}{l}\text { Nasirpur-1 } \\
\text { (U.P.) }\end{array}$ & Silt & 0.03 & $3 \cdot 6$ & $32 \cdot 7$ & $58 \cdot 2$ & $9 \cdot 1$ & $\begin{array}{l}\text { Major: Muscovite } \\
\text { chlorite, quartz. } \\
\text { Minor: Sodic } \\
\text { felspar, apatite, } \\
\text { magnetite, gar- } \\
\text { net. }\end{array}$ \\
\hline SEM-13 & $\begin{array}{l}\text { Ambakheri } \\
\text { (U.P.) }\end{array}$ & $\begin{array}{l}\text { Silty } \\
\text { sand }\end{array}$ & 0.09 & $5 \cdot 0$ & 41.9 & $41 \cdot 5$ & $16 \cdot 6$ & $\begin{array}{l}\text { Major: Quartz \& } \\
\text { muscovite } \\
\text { Minor; Biotite, } \\
\text { epidote, ortho- } \\
\text { clase, magnetite }\end{array}$ \\
\hline SEM-14 & $\begin{array}{l}\text { Nasirpur-2 } \\
\text { (U.P.) }\end{array}$ & $\begin{array}{l}\text { Sandy } \\
\text { silt }\end{array}$ & 0.035 & $4 \cdot 7$ & $15 \cdot 9$ & $62 \cdot 5$ & $21 \cdot 6$ & $\begin{array}{l}\text { Major: Muscovite, } \\
\text { chlorite, quartz } \\
\text { Minor: Sodic } \\
\text { felspar, apatite, } \\
\text { magnetite, gar- } \\
\text { net. }\end{array}$ \\
\hline
\end{tabular}




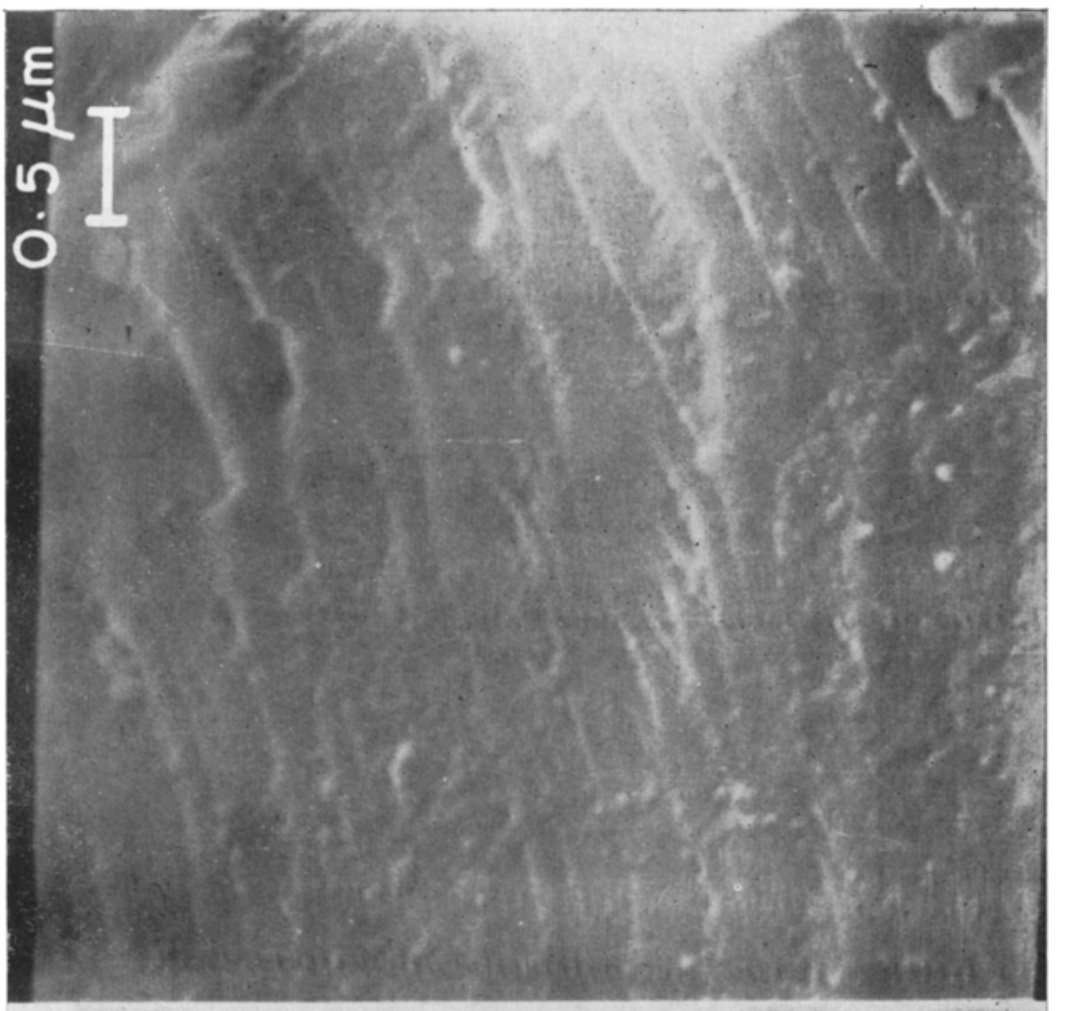

安焉

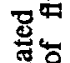

हึ

总

乎

8.9

果

ถ⿻ำ

용

줌

政.

$\overline{8}$

S

Fin

प्山े

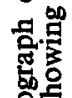

o

要

究善

i茫藏

on

案要
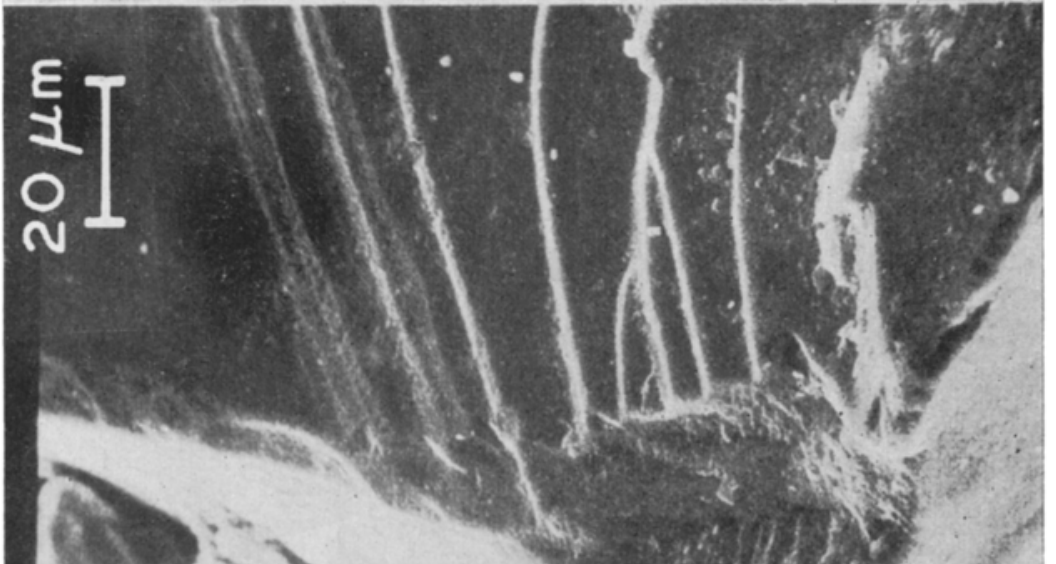

$\Xi$

解

葛

.

잉혈

๑ ठ

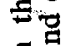

ह

온

들

때음

N

켱

碂

둥.

중

政

옹

当

.

$\sum_{\text {I }}$ 要

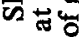

-

0

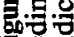




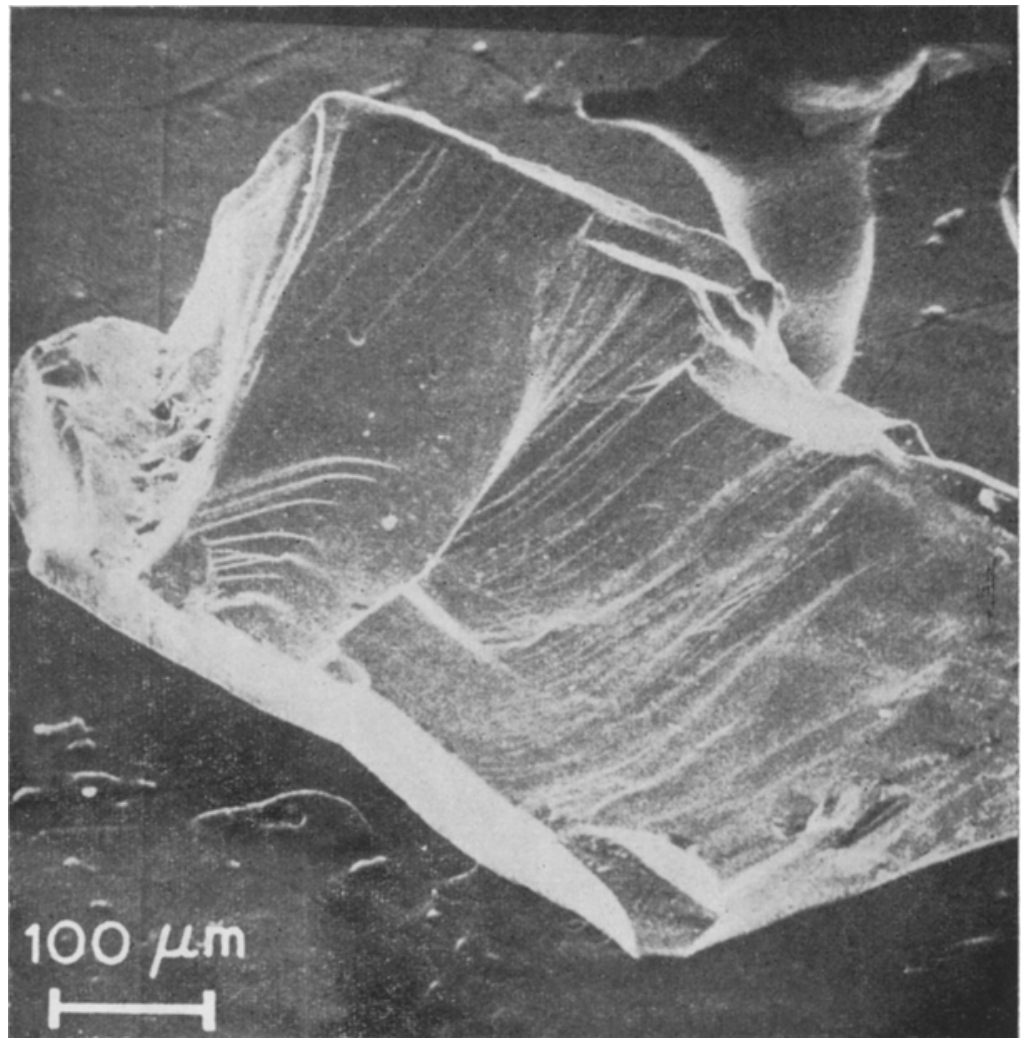

Figure 3. SEM micrograph of quartz grain showing a sub-angular shape and marks of conchoidal fracture indicative of glacio-fluvial transport. 


\section{SEM Studies}

Quartz grains (total 28; size $>0.25 \mathrm{~mm}$ ) were examined under the SEM, following the standard techniques of sample preparation (Krinsley and Doornkamp 1973). These techniques are fairly well established now and have been successfully applied to other Indian sediments, [Agrawal and Roy 1977; Pant et al, in press].

The grains showed distinct conchoidal fractures, parallel stepped structures, etc. indicating a glacial origin (figure 1). At higher magnifications one could see Vshaped pits indicating transportation through sub-aqueous environment (figure 2). No aeolian features like upturned cleavage plates, etc. could be detected. The grains, also were sub-angular (figure 3); none of them showing forsted and rounded shapes typical of aeolian transport.

The fluvial activity and the glacial features on the grains as also the presence of micaceous minerals, can be explained by the fact that the Gangetic river system originates in the Himalayan region. Aeolian activity is neither indicated by the sedimentologic and SEM analysis nor can it explain the source of micaceous material. The multiple evidences cited here thus show that the sediments were probably deposited during the waning stages of a flood in a near channel or levee environment.

\section{Discussion}

Even today, intense floods can leave 1-2 m of silt behind. During such floods, the OCP settlements must have been washed away. Some sherds must have got mixed up with the slush deposited in the silt left behind by the flood. The rolled and ochreous nature of the OCP sherds is also explained by flood water action. Since most of the sites are on the flood plain of the R. Ganges and its tributaries, no major lake created by tectonic uplifts (Lal 1968) need be invoked. Nor can one infer any aridity and aeolian activity (Lal 1971-72) from such sediments. In fact, the widespread OCP sediments indicate an intense flood activity which, if anything, could denote a heavier rainfall.

\section{Conclusions}

We thus see that the sedimentological, mineralogical and SEM analyses of the OCP associated sediments indicate intense and extensive flood activity which washed away the OCP settlements and left behind the silt which at places got mixed up with the OCP sherds and other artifacts. This devastation may also partly explain the considerable delay in the urbanization of the doab. Urbanization came to doab only in the first millennium B.C., whereas the first urban centres were thrown up by the Indus Civilization in Punjab and Rajasthan as early as the third millennium B.C.

\section{Acknowledgements}

We thank Dr R P Sharma for help in sample collection and $\mathbf{R} \mathbf{K}$ Setter in mechanical analysis. 


\section{References}

Agrawal D P 1971 The Copper-Bronze Age in India (New Delhi: Munshiram Manoharlal)

Agrawal D P and Roy B 1977 in Archaeology and Ecology of Western India eds D P Agrawal and B M Pande (New Delhi: Concept Pub.) p. 217

Blatt H, Middleton G and Murray R 1972 Origin of Sedimentary Rocks (New Jersey: Prentice Hall) Glennie K W 1970 Desert Sedimentary Environment (Amsterdam:Elsevier)

Huxtable J, Zimmerman D W, Hasan S N and Gaur R C 1972 Antiquity 46181

Krinsley D H and Doornkamp J C 1973 Atlas of quartz sand surface texture (Cambridge)

Lal B B 1968 Am. Anthropol. 70857

Lal B B 1971-72 Puratattva 549

Pant R K, Agrawal D P and Krishnamurthy R V Symposium on SEM in the Study of Sediments Swansea, Sept. 1977 (in press)

Sharma R P 1977 in Archaeology and Ecology of Western India eds D P Agrawal and B M Pande (New Delhi: Concept Pub.) p. 75 